\title{
MODIFICATION OF WHEATSTONE'S MICROPHONE AND ITS APPLICABILITY TO RADIOPHONIC RESEARCHES.
}

\section{By Alexander Graham Bell.}

A paper read betore the Philosophical society of Washington, I).C., June, 11, 1881.

In August, 1880, I directed attention to the fact that thin disks or diaphragms of various materials become sonorous when exposed to the action of an intermittent beam of sunlight, and I stated my belief that the sounds were due to molecular disturbances produced in the substance composing the diaphragm.* Shortly afterwards Lord Raleigh undertook a mathenatical investigation of the subjeet, and came to the conclusion that the audible effects were caused by the bending of the plates under unequal heating. $\dagger$ This explanation has reeently been called in question by Mr. Preece, who has expressed the opinion that although vilurations may be produced in the disks by the action of the intermittent bean, such vibrations are not the cause of the sonorous effeets observed. According to him, the arial disturbances that produce the sound arise spontaneously in the air itself by sudden expansion due to heat ammunicated from the diaphagm-every increase of heat giving rise to a fresh pulse of air. Mr. Preece was led to discard the theoretioal explanation of Lord Raleigh on account of the ficilure of experiments indertaken to test the theory. He was thus forced-ly the supposed insufficiency of the explanation - to seek in some wher alireetion the cunse of the phenomenon observed, and as a consequence he adopted the ingenious hypothesis alluded to above. But the experiments which had proved unsuccessful in the hands of Mr. Preece were perfectly successful when repeated in America under betier conditions of experiment, and the supposed necessity for another hypothesis at once vanished. I have shown in a recent paper read before the National Academy of science, || that audible sounds result from the expansion and contraction of the material exposed to the beam; and that a real to and fio vibration of the dia-

* Amer. Asso. for Advancement of Fejence, Aug. 27, 1880 .

† Nature, vol. xxiii, p. 274.

$\ddagger$ hoy. Sioc., Mar. 10, 1881 .

II April 21, 1381. 
phragm oceurs, capable of producing somorous effects. It has occurred to me that Mr. Preece's failure to detect with a delicate microphone the sonorous vibrations that were so easily observed in our experiments might be explained upon the supposition that he had employed the ordinary form of Hughes' microphone, shown in Fig. 1, and that the vibrating area was confined to the central portion of the disk. Under such eircumstances it might easily happen that both the supports $(A B)$ of the microphone might touch portions of the diaphragm which were practically at rest. It would of course be interesting to ascertain whether any such localization of the vibration as that supposed really oceurred, and I have great pleasure in showing to you to-night the apparatus by means of which this print has been investigated (see Fig. ․).

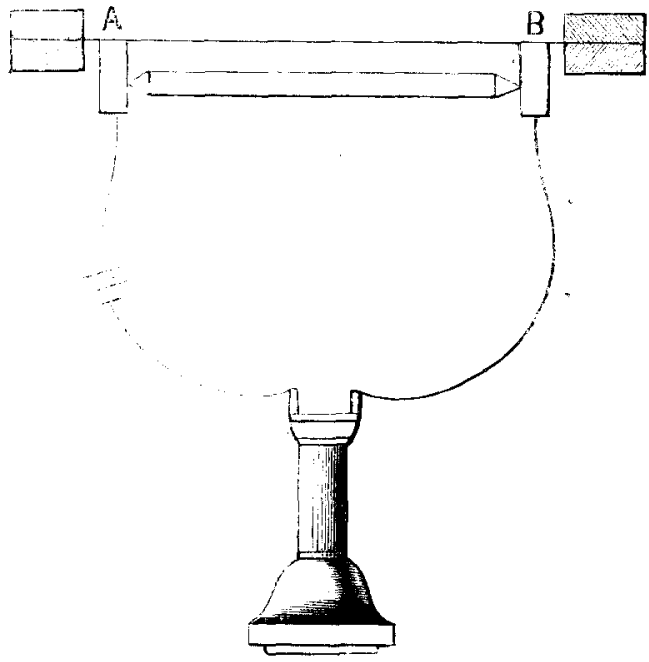

Fig. 1.

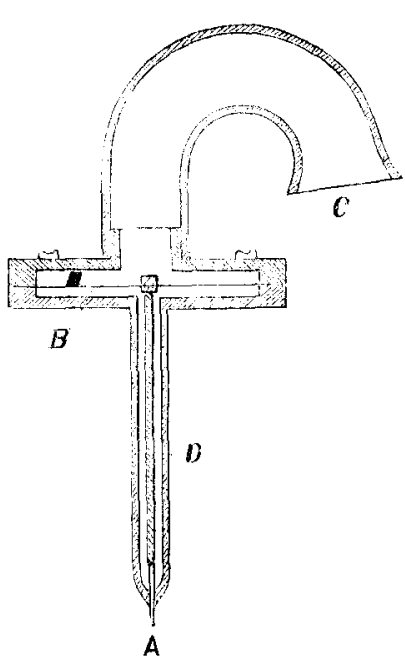

Fïig. 2.

The instrument is a modification of the form of microphone devised in 1827, by the late Sir Charles Wheatstone, and it consists essentially of a stiff wire $(A)$, one 3 end of which is rigidly attached to the centre of a metallic diaphragm $(B)$. In Wheatstone's original arrangement the diaphragm was placed directly against the ear, and the free extrenity of the wire was rested against some sounding body-like a wateh. In the present arrangement the diaphragm is clamped at the circumference like a telephone-diaphragn, and the sounds are con- 
veyed to the ear through a rubber hearing tube $(C)$. The wire passes. through the perforated handle $(I)$ ), and is exposed only at the extremity. When the wire $(A)$ was rested against the centre of a diaphragm upon which was focused an intermittent heam of sunlight a clear musical tone was perceived by applying the ear to the hearing tube $(C)$. The surfice of the diaphragm was then explored with the point of the microphone, and sounds were obtaing in all parts of the illuminated area and in the corre-ponding area on the other side of the diaphragm. Outside of this area on both siles of the diaphragm the sounds became. weaker and weaker until at a crtain distance from the centre they could no longer be pereivel.

At the points where one rould naturally place the supports of a Hughes microphone (see Fig. 1), no sound was observed. We were aliso unable to detect any audible effects when the point of the nicrophone was rested against the support to which the diaphragm was. attached. The negative results obtained in Europe by $\mathrm{Mr}$. Prece may therefore be reconeiled with the positive results obtained in America by Mr. Tainter and myself. A still more curions demonstration of localization of vibation oceured in the case of a large metallie mass. An intermittent beam of sunlight was focussed nom a brass weight (1 kilogram), and the surfice of the weight was then explored with the microphone shown in Fig. 2. A fecble but distinet sound was heard upon touching the surface within the illuminated area and for a short distance outside, but not in other parts.

In this experiment as in the ase of the thin diaphragm absolute contact between the point of the microphome and the surfice explored was necessary in order to obtain audible effects. Now I do not mean to deny that sound waves may be originated in the manner suggested by Mr. Preece, but I think that our experiments have demonstrated that the kind of action deseribed by Lord Raleigh actually oceurs, and that it is sufficient to account for the audible eflects obserwed.

\section{STORED-UP ELEOTRICITY: FAURE'S SECONDARY BITTERY.}

A few weeks since the scientific world in Paris was deeply interexted by a paper read before the Societé d'Encouragement de l'Industrie Nationale by M. Reynier, upon a new form of battery invented 